\title{
From Clone Selection to 80L Bioreactor Production: Better, Faster, Leaner
}

\author{
Marie-Françoise Clincke ${ }^{1 *}$, Frédéric Delouvroy ${ }^{1}$, Guillaume L Révérend ${ }^{1}$, Jimmy Stofferis ${ }^{1}$, Matthew Hinchliffe ${ }^{2}$, \\ Laetitia Malphettes $^{1}$ \\ From 24th European Society for Animal Cell Technology (ESACT) Meeting: C2P2: Cells, Culture, Patients, Products \\ Barcelona, Spain. 31 May - 3 June 2015
}

\section{Background}

Bio-pharmaceutical industries face an increasing demand to accelerate process development and reduce costs. Indeed as technologies mature, pressure on cost and timelines is greater for delivering scalable and robust processes. Here we present a novel method in order to speed up and interconnect clone selection with cell culture process development and scale up to $80 \mathrm{~L}$ scale.

\section{Materials and methods}

Ambr ${ }^{\mathrm{TM}} 48$ and $80 \mathrm{~L}$ stirred tank bioreactor were run for 14 days in a fed-batch mode in a chemically defined medium. A CHO cell line expressing a recombinant monoclonal antibody (MAb) was used. Feed was added daily from day 3 onwards. If required, antifoam $\mathrm{C}$ was added to the bioreactor. $\mathrm{DO}, \mathrm{pH}$, and temperature were controlled at setpoint. Viable cell concentration (VCC), cell viability, and average cell diameter were measured using a ViCell cell counter. Osmolality was obtained using an Osmometer (Advanced Instruments). On harvest day, MAb concentration of the supernatant samples was quantified using Protein A high performance liquid chromatography. For the minibioreactors run, triplicates were pooled on harvest day for product quality attributes analysis. For both scales cell culture fluid samples were centrifuged and filtered to remove cell debris. The monoclonal antibody was purified by ÄKTAXpress (GE Healthcare) Protein-A purification. The neutralized eluate was used for product quality analysis.

\footnotetext{
* Correspondence: Marie-Francoise.Clincke@ucb.com

${ }^{1}$ Upstream Process Sciences, BioTech Sciences, UCB Pharma S.A., Braine L'Alleud, Belgium

Full list of author information is available at the end of the article
}

\section{Results}

High throughput technologies enable us to interconnect clone and process development thus reducing the risks associated with early-stage process development while reducing timelines and enabling us to achieve higher process robustness in a leaner manner. In one ambr ${ }^{\mathrm{TM}} 48$ run different feeding strategies were assessed on 4 preselected lead clones for selecting the final lead clone, the fed-batch feeding strategy and additional data with feed compositions all at once. The selected condition (clone, type of feed and feeding strategy) was based on the maximization of the MAb titer and target High Molecular Weight Species (HMWS) level and Acidic Peak Group (APG) level (data not shown).

Scale up from ambr ${ }^{\mathrm{TM}} 48$ to $80 \mathrm{~L}$ stirred tank bioreactor was performed with the selected clone, feed and feeding strategy. Similar cell growth profiles were obtained at ambr ${ }^{\mathrm{TM}}$ scale and 80L scale for the selected condition (Figure 1).

Monoclonal Antibody titers and percentages of Acidic Peak Group obtained at harvest day were comparable between scales (Table 1). Process robustness was shown by performing a number of 4 batches at $80 \mathrm{~L}$ scale.

\section{Conclusions}

Selection of the lead clone together with the optimal feeding strategy was performed in one single $\mathrm{ambr}^{\mathrm{TM}}$ run and 16 conditions were tested in triplicate at the time of clone selection, compared to conventional approaches relying on 1L-10L stirred tank bioreactor experiments run on a single lead clone. Scale up was achieved successfully thus enabling early material production for downstream, formulation and analytical development. In conclusion, miniaturized bioreactors enabled us to interconnect clone and process design space selection and enable immediate $80 \mathrm{~L}$ production. 


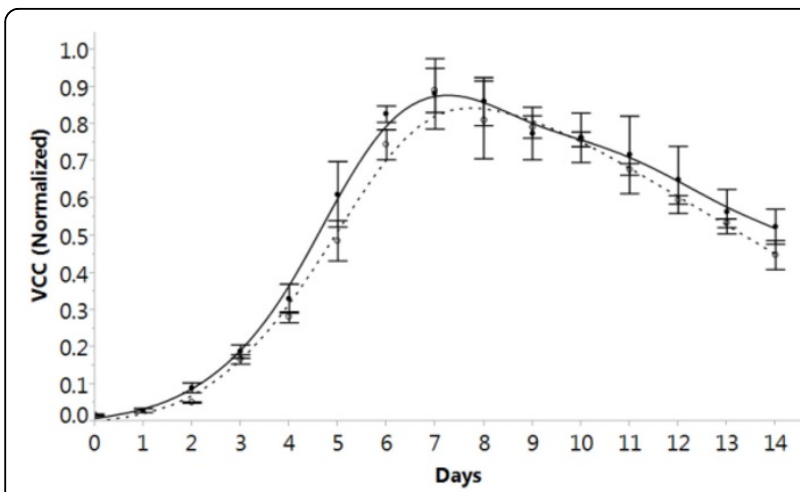

Figure 1 Viable cell concentration comparison between ambrTM and $80 \mathrm{~L}$ scales (solid black line: $80 \mathrm{~L}$ scale, dotted black line: ambris ${ }^{\mathrm{TM}}$ scale).

Table 1. MAbtiters and APG level obtained with the selected clone, feed and feeding strategy on harvest day at ambrTM and $80 \mathrm{~L}$ scales

\begin{tabular}{lll}
\hline & MAb titer (Normalized) & APG (Normalized) \\
\hline $\operatorname{ambr} \mathrm{TM}(n=3)$ & 0.9 & 0.7 \\
$80 \mathrm{~L}(\mathrm{n}=4)$ & 0.8 & 0.7 \\
\hline
\end{tabular}

\section{Authors' details}

${ }^{1}$ Upstream Process Sciences, BioTech Sciences, UCB Pharma S.A., Braine

L'Alleud, Belgium. ${ }^{2}$ Biology Research Discovery, Protein Expression \&

Purification, UCB Celltech, Slough, UK.

Published: 14 December 2015

doi:10.1186/1753-6561-9-S9-P34

Cite this article as: Clincke et al:: From Clone Selection to 80L Bioreactor Production: Better, Faster, Leaner. BMC Proceedings 2015 9(Suppl 9):P34.
Submit your next manuscript to BioMed Central and take full advantage of:

- Convenient online submission

- Thorough peer review

- No space constraints or color figure charges

- Immediate publication on acceptance

- Inclusion in PubMed, CAS, Scopus and Google Scholar

- Research which is freely available for redistribution

Submit your manuscript at www.biomedcentral.com/submit
C Biomed Central 